\title{
PENGARUH KUALITAS PRODUK, PROMOSI DAN HARGA TERHADAP KEPUTUSAN PEMBELIAN VARIASI AUDIO MOBIL DI SUBUR AUDIO WORKSHOP PURWOKERTO
}

\author{
Akbar Rakhman \\ Universitas Muhammadiyah Purwokerto \\ Tri Septin Muji Rahayu \\ Universitas Muhammadiyah Purwokerto
}

\begin{abstract}
This study aimed to analyze the effect of product quality, promotion, and price in the purchasing decision on car audio variations at consumer Subur Audioworkshop Purwokerto either partially or simultaneouslly. Methods used in sampling is sampling purposive sampling based on consideration for adjusting the criteria in order to improve the accuracy of the study sample. The analytical method used was multiple linear regression with the significant level ( $\alpha)$ of 0,05.

Results of this study showed that the quality of products significantly influence consumers' purchasing decisions, with significant value of 0,000 is less than 0,05. Variable promotion significantly influence consumers' purchasing decisions, with significant value of 0,001 is less than 0,05. Variable quality product significantly affect the purchasing decisions, with significant value of 0,000 is less than 0,05. Variable quality products, promotions and prices simultaneously influence the purchasing decisions of consumers, with a significant value of 0,000 is less than 0,05.
\end{abstract}

Keywords: Quality of Product, Promotion, Price and Purchase Decision

\section{ABSTRAK}

Penelitian ini bertujuan untuk menganalisis pengaruh kualitas produk, promosi, dan harga dalam keputusan pembelian konsumen pada variasi audio mobil Subur Audioworkshop Purwokerto baik secara parsial maupun secara simultan. Metode yang digunakan dalam pengambilan sampel adalah purposive sampling berdasarkan pertimbangan untuk menyesuaikan kriteria untuk meningkatkan akurasi sampel penelitian. Metode analisis yang digunakan adalah regresi linier berganda dengan tingkat signifikan $(\alpha)$ dari 0,05 .

Hasil penelitian ini menunjukkan bahwa kualitas produk berpengaruh secara signifikan terhadap keputusan pembelian konsumen, dengan nilai signifikan 0,000 kurang dari 0,05 . promosi variabel berpengaruh secara signifikan terhadap keputusan pembelian konsumen, dengan nilai signifikan 0,001 kurang dari 0,05. kualitas produk variabel signifikan mempengaruhi keputusan pembelian, dengan nilai signifikan 0,000 kurang dari 0,05 . produk-produk berkualitas variabel, promosi dan harga secara simultan mempengaruhi keputusan pembelian konsumen, dengan nilai signifikan 0,000 kurang dari 0,05.

Kata kunci: Kualitas Produk, Promosi, Harga dan Keputusan Pembelian.

\section{PENDAHULUAN}

Usaha variasi mobil di Indonesia semakin marak seiring dengan semakin banyaknya penjualan kendaraan mobil yang masuk di Indonesia. Perusahaan dituntut untuk selalu kreatif dan berinovasi untuk dapat bertahan dalam persaingan usaha variasi mobil. Kualitas variasi mobil yang ditawarkan diharapkan lebih unggul atau memiliki value yang lebih dari pesaing lainnya. Dengan demikian jasa variasi tersebut tetap memiliki daya tarik bagi konsumen.

Perilaku pembelian seseorang dapat dikatakan sesuatu yang unik, karena preferensi dan sikap terhadap obyek setiap orang berbeda. Selain itu konsumen berasal dari beberapa segmen, sehingga apa yang diinginkan dan dibutuhkan juga berbeda. Masih terdapat banyak faktor yang berpengaruh terhadap keputusan pembelian. Produsen perlu memahami perilaku konsumen terhadap produk atau merek yang ada di pasar, selanjutnya perlu dilakukan berbagai cara untuk membuat konsumen tertarik terhadap produk yang dihasilkan. Situasi persaingan usaha variasi 
mobil di Purwokerto semakin ketat. Ketatnya persaingan ini ditandai oleh banyaknya usaha variasi mobil mulai dari yang berskala kecil sampai yang besar.

Subur Audioworkshop merupakan anak perusahaan dari Suburban, yang bergerak dalam bidang jasa variasi mobil dan berdiri pada tanggal 10 April 1995, yang terletak di kota Purwokerto tepatnya di jalan Gerilya Timur No. 1124. Di pandang dari letak geografisnya kedudukan Subur Audioworkshop sudah cukup strategis, yaitu satu komplek dengan Suburban yang berada di pinggir jalan besar dan berdekatan dengan pompa bensin. Subur Audioworkshop mengutamakan kepuasan konsumen dengan cara memberikan produk yang berkualitas baik, untuk itu mereka tidak memberikan barang dengan kualitas rendah pada konsumen.

Variasi mobil sudah menjadi trend masa kini bagi pemilik kendaraan mobil. Subur Audioworkshop merupakan salah satu bengkel variasi mobil yang terkenal di Purwokerto. Dalam memberikan jasa variasi, perusahaan ini menggunakan aliran proses yang tidak jauh dengan perusahaan lain pada umumnya. Tetapi dalam kapasitas pelayanannya hingga saat ini sudah dapat memenuhi permintaan pasar. Layanan variasi yang dapat diberikan yaitu interior dan eksterior, diantaranya: Audio, Kulit jok, Kaca film, Body kit, Lampu HID, dan lain-lain.

Dalam memasarkan jasanya, Subur Audioworshop mencoba meyakinkan kepada para calon konsumennya dengan cara menyebarkan brosur yang berisikan gambar audio yang menarik beserta harga yang bermacam-macam, tidak hanya brosur, Subur Audioworkshop mencoba untuk mendekati para calon konsumennya melalui jejaring sosial/internet. Subur Audioworkshop seringkali mengadakan dan mengikuti pameran di berbagai tempat. Salah satu contoh lokasi keramaian yang dijadikan tempat pameran yaitu: Pasar Raya Moro, Pekan Raya Banyumas, dan lain-lain, di samping pusat jasa variasi yang sudah ada, seperti Indra variasi, Impala variasi dan masih banyak lagi, kehadiran Subur Audioworkshop telah menambah pusat pelayanan jasa variasi mobil bagi masyarakat Purwokerto.

Produk yang berkualitas dengan harga bersaing merupakan kunci utama dalam memenangkan persaingan, yang pada akhirnya akan dapat memberikan nilai kepuasan yang lebih tinggi kepada pelanggan. Pelanggan kini memiliki tuntutan nilai yang jauh lebih besar dan beragam karena pelanggan dihadapkan dengan berbagai pilihan berupa barang-barang atau jasa yang dapat mereka beli. Dalam hal ini penjual harus memberikan kualitas dan kepuasan terhadap suatu produk yang dapat diterima oleh konsumen, bila tidak pelanggan akan segera beralih kepada pesaing yang menyuguhkan kelebihan produknya kepada konsumen.

Niat untuk melakukan pembelian dapat terbentuk dari sikap konsumen terhadap bauran pemasaran diantaranya melalui promosi. Kegiatan promosi produk audio mobil diantaranya dapat dilakukan melalui periklanan, pemberian hadiah, potongan harga, dan personal selling. Sejalan dengan itu, keputusan konsumen dalam pembelian produk audio mobil dapat dipengaruhi oleh stimuli atau rangsangan pemasaran seperti kualitas produk, promosi melalui iklan yang menarik, diskon, hadiah. Selain itu desain turut mempengaruhi keputusan pembelian. Umumnya konsumen menginginkan desain yang inovatif dari waktu ke waktu.

Berdasarkan uraian di atas yang menjadi pokok permasalahan adalah sejauh mana kualitas produk, promosi, dan harga berpengaruh terhadap keputusan pembelian produk audio mobil pada pelanggan Subur Audioworkshop Purwokerto. Penelitian ini merupakan replikasi dari penelitian Wijayanti (2006) tentang pengaruh harga, kualitas produk terhadap keputusan pembelian Toyota kijang (studi kasus pada PT Nasmoco Kaligawe Semarang). Penelitian dilakukan untuk mengetahui bahwa harga, kualitas produk berpengaruh positif dan signifikan terhadap keputusan pembeli Toyota Kijang pada PT.Nasmoco Kaligawe Semarang. Namun ada sedikit perubahan dalam penelitian ini dengan jurnal replikasi yaitu beberapa variabel dan objek yang digunakan. Berdasarkan uraian di atas, maka peneliti mengambil judul "Pengaruh kualitas produk, promosi dan harga terhadap keputusan pembeliasan variasi audio mobil di Subur Audioworkshop Purwokerto". 


\section{TUJUAN PENELITIAN}

1. Untuk mengetahui pengaruh kualitas produk, promosi, dan harga terhadap keputusan pembelian variasi audio mobil pada konsumen Subur Audioworkshop Purwokerto baik secara sendiri-sendiri maupun secara bersama-sama.

2. Untuk mengetahui faktor yang mempunyai pengaruh dominan terhadap keputusan pembelian variasi audio mobil pada konsumen Subur Audioworkshop Purwokerto. berikut:

Berdasarkan uraian diatas maka hipotesis dalam penelitian ini dapat dirumuskan sebagai

$\mathrm{H} 1$ : $\quad$ Kualitas produk $\left(\mathrm{X}_{1}\right)$ berpengaruh signifikan terhadap keputusan pembelian konsumen $(\mathrm{Y})$

$\mathrm{H} 2$ : $\quad$ Promosi $\left(\mathrm{X}_{2}\right)$ berpengaruh signifikan terhadap keputusan pembelian konsumen $(\mathrm{Y})$

H3 : $\quad \operatorname{Harga}\left(\mathrm{X}_{3}\right)$ berpengaruh signifikan terhadap keputusan pembelian konsumen $(\mathrm{Y})$

$\mathrm{H} 4$ : $\quad$ Kualitas produk $\left(\mathrm{X}_{1}\right)$, promosi $\left(\mathrm{X}_{2}\right)$, harga $\left(\mathrm{X}_{3}\right)$ berpengaruh secara simultan terhadap keputusan pembelian konsumen $(\mathrm{Y})$

\section{METODOLOGI PENELITIAN}

\section{Populasi dan Sampel}

Populasi dalam penelitian ini adalah konsumen Subur Audioworkshop Purwokerto yang membeli variasi audio mobil. Menurut Arikunto (2002) untuk sampel apabila subjeknya kurang dari 100 lebih baik diambil semua sehingga penelitiannya merupakan penelitian populasi. Sedangkan metode pengambilan sampel yang digunakan dalam penelitian ini adalah metode purposive sampling, yaitu pengambilan sampel yang didasarkan pada pertimbangan untuk menyesuaikan dengan kriteria penelitian agar dapat meningkatkan ketepatan sampel (Sugiyono, 1999). Kriteria tersebut yaitu pelanggan yang sudah pernah membeli variasi audio mobil di Subur Audioworkshop periode tahun 2010 sampai dengan 2012.

\section{Definisi Operasional}

a) Kualitas produk

Kualitas produk merupakan kemampuan yang biasa dinilai dari suatu produk dalam menjalankan fungsinya yang merupakan suatu gabungan. Kualitas produk adalah kemampuan suatu produk untuk memuaskan kebutuhan dan harapan konsumen (Bergman dan Klefsjo, 1994). Indikator yang di pakai adalah:

1) Variasi audio mobil yang sempurna dan bebas dari cacat.

2) Ketahanan variasi audio mobil yang tidak mudah rusak.

3) Suara audio yang enak didengar.

4) Penampilan desain variasi audio mobil yang unik dan menarik.

5) Warna yang tidak mudah pudar.

\section{b) Promosi}

Menurut Swastha dan Irawan (2005) promosi pada hakikatnya adalah suatu bentuk komunikasi pemasaran yang bertujuan mendorong permintaan, yang dimaksud komunikasi pemasaran adalah aktivitas pemasaran yang berusaha menyebarkan informasi, mempengaruhi dan atau mengingatkan pasar sasaran atas perusahaan dan produknya agar bersedia menerima, membeli, dan loyal pada produk atau jasa yang ditawarkan perusahaan yang bersangkutan. Indikator yang dipakai dalam penelitian ini adalah:

1) Kualitas penyampaian pesan dalam iklan di media promosi.

2) Periklanan yang dapat mempengaruhi kepuasan konsumen.

3) Kuantitas penayangan iklan di media promosi.

4) Jangkauan promosi. 
c) Harga

Harga adalah jumlah uang (ditambah beberapa produk kalau mungkin) yang dibutuhkan untuk mendapatkan sejumlah kombinasi dari produk dan pelayanannya (Swasta dan Irawan, 2005). Dilihat dari sudut pandang pemasaran, harga adalah jumlah uang yang ditagihkan untuk suatu produk atau jasa. Indikator yang digunakan untuk mengukur adalah:

1) Kesesuaian perbandingan harga dengan kualitas produk.

2) Harga yang ekonomis.

3) Perbandingan harga dengan perusahaan variasi audio mobil lain.

4) Tersedianya beragam pilihan harga.

5) Terdapat harga khusus/promo.

d) Keputusan pembelian

Keputusan pembelian adalah hal-hal yang dipertimbangkan konsumen sebelum memutuskan untuk membeli produk, antara lain: merek, kualitas produk, dan harga sehingga dapat membentuk loyalitas terhadap produk. Indikator keputusan pembelian antara lain:

1) Kesadaran akan kebutuhan.

2) Pilihan Alternatif.

3) Kemantapan pada sebuah produk.

4) Rekomendasi dari orang lain.

5) Pelanggan tetap.

\section{Alat analisis yang digunakan}

a. Analisis Regresi Linier Berganda

Pengujain hipotesis dalam penelitain ini menggunakan regresi linier berganda dimaksudkan untuk menguji pengaruh pelatihan kerja, pengembangan karir dan lingkungan kerja terhadap kinerja pegawai di Dinas Cipta Karya Kabupaten Banyumas. Adapun bentuk persamaan regresinya adalah sebagai berikut (Supranto, 2000):

$$
Y=\mathrm{a}+\mathrm{b}_{1} \mathrm{X}_{1}+\mathrm{b}_{2} \mathrm{X}_{2}+\mathrm{b}_{3} \mathrm{X}_{3}+e
$$

dimana:

$\mathrm{Y}=$ Keputusan pembelian (variabel dependen)

$\mathrm{X}_{1}=$ Variabel kualitas produk (variabel independen)

$\mathrm{X}_{2} \quad=$ Variabel harga (variabel independen)

$\mathrm{X}_{3}=$ Variabel iklan (variabel independen)

$\mathrm{a}_{3} \quad=$ Konstanta.

$\mathrm{b}_{1} \quad=$ Koefisien regresi variabel kualitas produk

$\mathrm{b}_{2} \quad=$ Koefisien regresi variabel harga

$\mathrm{b}_{3} \quad=$ Koefisien regresi variabel iklan

$e^{3}=$ error

\section{HASIL DAN PEMBAHASAN}

\section{Pengujian Hipotesis dan Pembahasan}

Hasil penelitian ini menunjukkan bahwa pengujian validitas dan reliabilitas serta uji asumsi klasik model regresi sudah terbebas dari permasalahan normalitas, multikolinearitas dan heteroskedastisitas. Dengan demikian model regresi sudah tepat digunakan dalam pengujian hipotesis dalam penelitian ini.

Tabel 1. Hasil Olah Data Regresi Berganda

Coefficients $^{\mathrm{a}}$

\begin{tabular}{|l|r|r|r|r|r|}
\hline \multirow{2}{*}{ Model } & \multicolumn{2}{|c|}{$\begin{array}{c}\text { Unstandardized } \\
\text { Coefficients }\end{array}$} & $\begin{array}{c}\text { Standardized } \\
\text { Coefficients }\end{array}$ & & \\
\cline { 2 - 5 } & B & Std. Error & Beta & t & Sig. \\
\hline 1 (Constant) & .465 & .262 & & 1.777 & .078 \\
\hline
\end{tabular}




\begin{tabular}{|l|l|l|l|l|l|}
\hline Kualitas Produk & .361 & .096 & .397 & 3.748 & .000 \\
Promosi & .212 & .063 & .301 & 3.358 & .001 \\
Harga & .268 & .079 & .259 & 3.394 & .001 \\
\hline
\end{tabular}

a. Dependent Variable: Keputusan Pembelian

Berdasarkan tabel tersebut dapat disusun persamaan regresi sebagai beriku: $\mathrm{Y}=0,465+0,361 \mathrm{X}_{1}+0,212 \mathrm{X}_{2}+0,268 \mathrm{X}_{3}$

Adapun interpretasi dari persamaan regresi tersebut adalah:

$\alpha=0,465$ artinya keputusan pembelian konsumen sebesar 0,465 satuan jika kualitas produk, promosi dan harga bernilai nol.

$\beta_{1}=0,361$ artinya keputusan pembelian konsumen akan meningkat sebesar 0,361 satuan apabila kualitas produk naik satu satuan dengan asumsi promosi dan harga bernilai tetap.

$\beta_{2}=0,212$ artinya keputusan pembelian konsumen akan meningkat sebesar 0,212 satuan apabila promosi naik satu satuan dengan asumsi kualitas produk, dan harga bernilai tetap.

$\beta 3=0,268$ artinya keputusan pembelian konsumen akan meningkat sebesar 0,268 satuan apabila harga naik satu satuan dengan asumsi kualitas produk dan promosi bernilai tetap.

\section{Pengujian Hipotesis}

1. Hipotesis Pertama

Berdasarkan tabel 4.10 diketahui bahwa variabel kualitas produk memiliki nilai thitung sebesar 3,748 sedangkan nilai $t_{\text {tabel }}$ sebesar 1,9840 dengan demikian $t_{\text {hitung }}>t_{\text {tabel }}$ yaitu 3,748 $>1,9840$ serta nilai signifikan sebesar 0,000 kurang dari 0,05 . Hal ini berarti kualitas produk berpengaruh signifikan terhadap keputusan pembelian konsumen, dengan demikian hipotesis pertama diterima.

2. Hipotesis Kedua

Berdasarkan tabel 4.10 diketahui bahwa variabel promosi memiliki nilai $t_{\text {hitung }}$ sebesar 3,358 sedangkan nilai $t_{\text {tabel }}$ sebesar 1,9840 dengan demikian $t_{\text {hitung }}>t_{\text {tabel }}$ yaitu 3,358 $>1,9840$ serta nilai signifikan sebesar 0,001 kurang dari 0,05. Hal ini berarti promosi berpengaruh signifikan terhadap keputusan pembelian konsumen, dengan demikian hipotesis kedua diterima.

\section{Hipotesis Ketiga}

Berdasarkan tabel 4.10 diketahui bahwa variabel harga memiliki nilai thitung sebesar 3,394 sedangkan nilai $t_{\text {tabel }}$ sebesar 1,9840 dengan demikian $t_{\text {hitung }}>t_{\text {tabel }}$ yaitu 3,394 $>1,9840$ serta nilai signifikan sebesar 0,000 kurang dari 0,05 . Hal ini berarti harga berpengaruh signifikan terhadap keputusan pembelian konsumen, dengan demikian hipotesis ketiga diterima.

4. Hipotesis Keempat

Untuk menguji pengaruh kualitas produk, promosi dan harga secara simultan terhadap keputusan pembelian konsumen, menggunakan uji F. Hasil uji F dapat dilihat dalam Tabel 2.

Tabel 2 Hasil Uji F

ANOVA $^{\mathrm{b}}$

\begin{tabular}{|l|r|r|r|r|r|}
\hline Model & Sum of Squares & df & Mean Square & F & Sig. \\
\hline $1 \quad$ Regression & 17.397 & 3 & 5.799 & 60.234 & $.000^{a}$ \\
Residual & 10.494 & 109 & .096 & & \\
Total & 27.891 & 112 & & & \\
\hline
\end{tabular}

a. Predictors: (Constant), Harga, Promosi, Kualitas Produk

b. Dependent Variable: Keputusan Pembelian 
Berdasarkan tabel tersebut diketahui besarnya $F_{\text {hitung }}$ adalah sebesar 60,234, sedangkan nilai $F_{\text {tabel }}$ sebesar 2,70. Sehingga diketahui $F_{\text {hitung }}>F_{\text {tabel, }}$ yaitu 60,234 $>2,70$ serta dengan nilai signifikan sebesar 0,000 kurang dari 0,05. Dengan demikian kualitas produk, promosi dan harga secara simultan berpengaruh terhadap keputusan pembelian konsumen, sehingga hipotesis keempat diterima.

Untuk mengetahui seberapa besar pengaruh kualitas produk, promosi dan harga terhadap keputusan pembelian konsumen dapat dilihat melalui nilai Adjusted $\mathrm{R}^{2}$, hasil uji Adjusted $\mathrm{R}^{2}$ dapat dilihat dalam tabel sebagai berikut:

Tabel 3. Hasil Uji Adjusted $\mathbf{R}^{2}$

Model Summary

\begin{tabular}{|l|r|r|r|c|}
\hline Model & \multicolumn{1}{|c|}{$\mathrm{R}$} & $\mathrm{R}$ Square & $\begin{array}{c}\text { Adjusted R } \\
\text { Square }\end{array}$ & $\begin{array}{c}\text { Std. Error of the } \\
\text { Estimate }\end{array}$ \\
\hline 1 & $.790^{\mathrm{a}}$ & .624 & .613 & .31028 \\
\hline
\end{tabular}

a. Predictors: (Constant), Harga, Promosi, Kualitas Produk

Berdasarkan tabel tersebut diketahui nilai Adjusted $\mathrm{R}^{2}$ sebesar 0,613, hal ini berarti variabel kualitas produk, promosi dan harga mempengaruhi keputusan pembelian konsumen sebesar $61,3 \%$, sedangkan sisanya sebesar $38,7 \%$ dipengaruhi oleh faktor lain yang tidak diteliti.

\section{Pembahasan}

Penelitian ini bertujuan untuk mengetahui pengaruh kualitas produk, promosi dan harga terhadap keputusan pembelian konsumen baik secara simultan maupun parsial. Hasil penelitian ini menunjukkan bahwa pengujian asumsi klasik model regresi sudah terbebas dari permasalahan normalitas, multikolinearitas dan heteroskedastisitas sehingga model regresi sudah tepat digunakan dalam pengujian hipotesis dalam penelitian ini.

Kualitas produk berpengaruh signifikan terhadap keputusan pembelian konsumen. Hal ini dikarenakan banyak konsumen memutuskan untuk membeli produk yang berkualias tinggi. Hal ini didukung dengan skor rata variabel kualitas produk sebesar 3,62 mendekati skor 4, yang artinya kualitas produk masuk dalam kategori tinggi. Menurut Kotler dan Amstrong (1997) kualitas adalah karakteristik dari produk dalam kemampuan untuk memenuhi kebutuhan-kebutuhan yang telah ditentukan dan bersifat laten. Untuk mencapai kualitas produk yang diinginkan maka diperlukan suatu standarisasi kualitas. Cara ini dimaksudkan untuk menjaga agar produk yang dihasilkan memenuhi standar yang telah ditetapkan sehingga konsumen tidak akan kehilangan kepercayaan terhadap produk yang bersangkutan. Pemasar yang tidak memperhatikan kualitas produk yang ditawarkan akan menanggung tidak loyalnya konsumen sehingga penjualan produknya pun akan cenderung menurun. Jika pemasar memperhatikan kualitas, bahkan diperkuat dengan periklanan dan harga yang wajar maka konsumen tidak akan berpikir panjang untuk melakukan pembelian terhadap produk. Penelitian ini sejalan dengan penelitian Wijayanti (2006) tentang pengaruh harga, kualitas produk terhadap keputusan pembelian Toyota kijang (studi kasus pada PT. Nasmoco Kaligawe Semarang). Penelitian menemukan bukti bahwa kualitas produk berpengaruh positif dan signifikan terhadap keputusan pembeli Toyota Kijang pada PT. Nasmoco Kaligawe Semarang.

Promosi berpengaruh signifikan terhadap keputusan pembelian konsumen. Hal ini karena konsumen melakukan pembelian karena melihat promosi yang dilakukan. Menurut Swastha dan Irawan (2005) promosi pada hakikatnya adalah suatu bentuk komunikasi pemasaran yang bertujuan mendorong permintaan, yang dimaksud komunikasi pemasaran adalah aktivitas pemasaran yang berusaha menyebarkan informasi, mempengaruhi dan atau mengingatkan pasar sasaran atas perusahaan dan produknya agar bersedia menerima, membeli, dan loyal pada produk atau jasa yang ditawarkan perusahaan yang bersangkutan. Penelitian ini sejalan dengan penelitian Maulana (2004) melakukan penelitian dengan judul pengaruh kualitas produk, harga dan promosi terhadap keputusan pembelian. Hasil penelitian tersebut menunjukkan pengaruh yang positif dan signifikan promosi terhadap keputusan pembelian. 
Harga berpengaruh signifikan terhadap keputusan pembelian konsumen. Hal ini karena harga yang terjangkau membuat konsumen melakukan pembelian produk. Hal ini didukung dengan skor rata variabel harga sebesar 4, yang artinya harga masuk dalam kategori tinggi. Harga menurut Umar (2000) adalah "sejumlah nilai yang ditukarkan konsumen dengan manfaat dari memiliki atau menggunakan produk atau jasa yang nilainya ditetapkan oleh pembeli dan penjual melalui tawar menawar, atau ditetapkan oleh penjual untuk satu harga yang sama terhadap semua pembeli". Penelitian ini sejalan dengan penelitian Wijayanti (2006) tentang pengaruh harga, kualitas produk terhadap keputusan pembelian Toyota kijang (studi kasus pada PT. Nasmoco Kaligawe Semarang). Penelitian menemukan bukti bahwa harga berpengaruh positif dan signifikan terhadap keputusan pembeli Toyota Kijang pada PT. Nasmoco Kaligawe Semarang.

Kualitas produk, promosi dan harga secara simultan berpengaruh terhadap keputusan pembelian konsumen. Hal ini berarti keputusan pembelian konsumen Subur Audioworkshop Purwokerto dipengaruhi kualitas produk, promosi dan harga. Penelitian ini sejalan dengan penelitian Maulana (2004) melakukan penelitian dengan judul pengaruh kualitas produk, harga dan promosi terhadap keputusan pembelian. Hasil penelitian tersebut menunjukkan kualitas produk, harga dan promosi berpengaruh terhadap keputusan pembelian.

Penelitian ini memilik kelebihan yaitu tingginya nilai $\mathrm{R}^{2}$ yaitu sebesar 0,624 , hal ini berarti variabel kualitas produk, promosi dan harga mempengaruhi keputusan pembelian konsumen sebesar $62,4 \%$, sedangkan sisanya sebesar $37,6 \%$ dipengaruhi oleh faktor lain yang tidak diteliti. Selain hal tersebut penelitian ini juga menemukan bukti bahwa kualitas produk, harga dan promosi berpengaruh terhadap keputusan pembelian baik secara parsial maupun simultan. Selain memiliki kelebihan penelitian ini juga memiliki kelemahan yaitu terdapat data yang menyimpang sehingga perlu dikeluarkan dari analisis.

Untuk meningkatkan promosi, kualitas produk dan harga maka perlu dianalisis dengan melihat score yan kurang atau rendah pada butir kuesioner pada setiap variabel. Berdasarkan analisis diketahui bahwa pada variabel kualitas produk item pertanyaan nomor 2 dan 4 memiliki rata-rata sebesar 3,45 dan 3,21 kurang dari 3,5 yaitu pertanyaan tentang audio mobil tidak mudah rusak, sehingga mempunyai umur ekonomis yang lama dan penampilan desain variasi audio mobil yang unik dan menarik. Hal ini berarti pada item pertanyaan tersebut respon responden masih rendah. Dengan demikian untuk meningkatkan kualitas produk sebaiknya perusahaan memberikan audio mobil yang baik dan dengan penampilan desain yang bervariasi.

Pada variabel promosi semua item pertanyaan memiliki rata-rata kurang dari 3,5 yaitu sebesar 2,80, 3,23, 3,25 dan 3,32 yaitu pertanyaan tentang tayangan/gambar iklan Subur Audioworkshop lebih menarik dan atraktif, bahasa promosi dan iklan yang sesuai dengan kenyataan produk, promosi dengan berbagai media yang mudah diakses oleh masyarakat dan adanya pameran yang menjadikan ketertarikan untuk membeli variasi audio mobil di Subur Audioworkshop. Hal ini berarti pada variabel promosi respon responden masih rendah. Dengan demikian untuk meningkatkan promosi sebaiknya perusahaan membuat tayangan/gambar iklan Subur Audioworkshop lebih menarik dan atraktif, bahasa promosi dan iklan yang sesuai dengan kenyataan produk, promosi dengan berbagai media yang mudah diakses oleh masyarakat dan adanya pameran yang menjadikan ketertarikan untuk membeli variasi audio mobil di Subur Audioworkshop.

Pada variabel harga semua item pertanyaan memiliki rata-rata lebih dari 3,5 yaitu sebesar $4,32,4,00,3,82,4,13$ dan 3,73. Hal ini berarti pada variabel harga respon responden sudah baik dan perlu dipertahanakan.

Pada variabel keputusan pembelian item pertanyaan nomor 2, 3 dan 5 memiliki rata-rata sebesar 3,41, 3,22 dan 3,26 kurang dari 3,5 yaitu pertanyaan tentang Subur Audioworkshop menjadi pilihan alternatif, membeli variasi audio mobil di Subur Audioworksop merupakan keputusan yang tepat dan karena sudah menjadi pelanggan tetap. Hal ini berarti pada item pertanyaan tersebut respon responden masih rendah. Dengan demikian untuk meningkatkan keputusan konsumen untuk melakukan pembelian di Subur Audioworkshop Purwokerto sebaiknya perusahaan memberikan harga yang terjangkau, lebih murah dan memberikan promo harga khusus. 


\section{KESIMPULAN DAN SARAN}

\section{Kesimpulan}

1) Kualitas produk berpengaruh signifikan terhadap keputusan pembelian konsumen. Hal ini ditunjukkan dengan nilai $t_{\text {hitung }}>\mathrm{t}_{\text {tabel }}$ yaitu 3,748 $>1,9840$ serta nilai signifikan sebesar 0,000 kurang dari 0,05 .

2) Promosi berpengaruh signifikan terhadap keputusan pembelian konsumen. Hal ini ditunjukkan dengan nilai $t_{\text {hitung }}>t_{\text {tabel }}$ yaitu 3,358 $>1,9840$ serta nilai signifikan sebesar 0,001 kurang dari 0,05 .

3) Kualitas produk berpengaruh signifikan terhadap keputusan pembelian konsumen. Hal ini ditunjukkan dengan nilai $t_{\text {hitung }}>\mathrm{t}_{\text {tabel }}$ yaitu 3,394 $>1,9840$ serta nilai signifikan sebesar 0,000 kurang dari 0,05 .

4) Kualitas produk, promosi dan harga secara simultan berpengaruh terhadap keputusan pembelian konsumen. Hal ini ditunjukkan dengan nilai $F_{\text {hitung }}>F_{\text {tabel, }}$ yaitu 60,234 2,70 serta dengan nilai signifikan sebesar 0,000 kurang dari 0,05.

\section{Saran}

1). Bagi Pimpinan Subur Audioworkshop Purwokerto, sebaiknya:

a. Untuk meningkatkan kualitas produk sebaiknya perusahaan memberikan audio mobil yang baik dan dengan penampilan desain yang bervariasi

b. Untuk meningkatkan promosi sebaiknya perusahaan membuat tayangan/gambar iklan Subur Audioworkshop lebih menarik dan atraktif, bahasa promosi dan iklan yang sesuai dengan kenyataan produk, promosi dengan berbagai media yang mudah diakses oleh masyarakat dan adanya pameran yang menjadikan ketertarikan untuk membeli variasi audio mobil di Subur Audioworkshop

c. Untuk meningkatkan keputusan konsumen untuk melakukan pembelian di Subur Audioworkshop Purwokerto sebaiknya perusahaan menjadi pilihan alternatif, tempat membeli variasi audio mobil di Subur Audioworksop merupakan keputusan yang tepat dan karena sudah menjadi pelanggan tetap

d. Lebih meningkatkan promosi terutama melalui media televisi sehingga lebih banyak konsumen yang melakukan pembelian di Subur Audioworkshop Purwokerto.

2). Bagi konsumen, sebaiknya lebih memperhatikan harga dalam melakukan pembelian di Subur Audioworkshop Purwokerto karena pada penelitian ini tidak terdapat item yang nilai rata-ratanya kurang dari 3,5.

\section{DAFTAR PUSTAKA}

Agusty Tae Ferdinand. 2006. Metode Penelitian Manajemen. Edisi II. Badan Penerbit Universitas Diponegoro. Semarang.

Angipora, Marius. 2002. Dasar-Dasar Pemasaran. Edisi Kedua. PT Raja Grafindo Persada. Jakarta.

Arikunto, S. 2002. Prosedur Penelitian Suatu Pendekatan Praktik. Rineka cipta. Jakarta.

Bergman, Bo. dan Klefsjo, B. 1994. Kualitas: Dari Kebutuhan Pelanggan Terhadap Kepuasan Pelanggan. Perusahaan Buku McGrawhill. London.

Dharmesta dan Irawan. 2001. Manajemen Pemasaran Modern. Edisi Kedua. Liberty. Yogyakarta.

D.A. Garvin. 1994. Kualitas Produk. Alat Strategi Yang Penting. Free Press.

Echols, John M. 1975. Kamus Inggris-Indonesia. PT.Gramedia. Jakarta.

Engel, James. 1994. Perilaku Konsumen. Binarupa Aksara. Jakarta.

Ghozali, Imam. 2001. Aplikasi Analisis dengan Program SPSS. Undip. Semarang. 
2002. Aplikasi Analisis Multivariate Prograp SPSS. Badan Penerbit Universitas Diponegoro. Semarang.

Indriantoro, Nur. dan Supomo, Bambang. 2002. Metodologi Penelitian Bisnis. Cetakan Kedua. Penerbit BFEE UGM. Yogyakarta.

Kotler, Philip. 1993. Manajemen Pemasaran Analisis. Perencanaan, Implementasi dan Kontrol. PT Prenhallindo. Jakarta.

1997. Dasar-Dasar Pemasaran. Prenhallindo. Jakarta.

1997. Prinsip-Prinsip Pemasaran. Erlangga.

2001. Manajemen Pemasaran. Edisi II. PT Indeks. Jakarta.

2002. Manajemen Pemasaran. Edisi Millenium. Jilid 2. PT Prenhallindo. Jakarta.

Lupiyoadi, Rambat dan Hamdani, A. 2001. Manajemen Pemasaran Jasa. Salemba Empat. Jakarta.

Mas'ud, Fuad. 2004. Survai Diagnosis Organisasional, Konsep dan Aplikasi. Badan Penerbit UNDIP. Semarang.

Mowen, Jhon. C, dan Minor, Michael. 2002. Perilaku Konsumen. Binarupa Aksara. Jakarta.

Setiadi, J. Nugroho. 2003. Perilaku Konsumen, Konsep dan Implikasi Untuk Strategi dan Penelitian Bisnis Pemasaran. Prenada Media. Jakarta.

Stanton, William J. 1995. Prinsip Pemasaran. Cetakan Keempat. Edisi Ketujuh. Erlangga. Jakarta.

Sugiyono, 1999. Metode Penelitian Bisnis. Penerbit CV Alfabeta. Bandung.

2004. Metode Penelitian Bisnis. Alfabeta. Bandung.

Swastha, Basu. 2001. Manajemen Pemasaran Modern. BPFE. Yogyakarta. . 1997. Manajemen Pemasaran Perilaku Konsumen. Edisi 3. Liberty. Yogyakarta. 2005. Manajemen Pemasaran Modern. Liberty. Yogyakarta.

Tjiptono, Fandy. 2001. Strategi Pemasaran. Yogyakarta. Penerbit Andi.

2002. Strategi Pemasaran. Andy Offset. Yogyakarta.

Umar, Husein. 2000. Riset Pemasaran dan Perilaku Konsumen. Gramedia Pustaka Utama dan Jakarta Business Center. Jakarta.

. 2002. Riset Pemasaran dan Perilaku Konsumen. PT Gramedia Pustaka Utama. Jakarta.

2003. Metode Riset Bisnis. PT Gramedia Pustaka Utama. Jakarta. 